Research Article

\title{
Developing audio-visual learning media based on video documentary on tissue culture explant of Dendrobium bigibbum
}

\author{
M. Mellisa a,1,*, Yola Dwi Yanda ${ }^{2}$ \\ a Biology Education Study Program, Faculty of Teacher Training and Education, Universitas Islam Riau, Jl. Kaharuddin No. 113, \\ Simpang Tiga, Pekan Baru, Riau 28284, Indonesia \\ 1 mellisabio@edu.uir.ac.id *; ${ }^{2}$ yoladwiyanda@gmail.com \\ ${ }^{*}$ Corresponding author
}

\begin{tabular}{|c|c|}
\hline ARTICLE INFO & ABSTRACT \\
\hline $\begin{array}{l}\text { Article history } \\
\text { Received October 10, } 2019 \\
\text { Revised October 30, } 2019 \\
\text { Accepted November 19, } 2019 \\
\text { Published November 30, } 2019 \\
\\
\text { Keywords } \\
\text { ADDIE model } \\
\text { Audio-visual } \\
\text { Learning media } \\
\text { R \& D } \\
\text { Tissue culture }\end{array}$ & $\begin{array}{l}\text { The development of science and technology challenge teachers to pay a great effort in } \\
\text { creating an effective media. The aim of this study was to produce audio-visual learning } \\
\text { media based on video documentary explanation of orchid plants (Dendrobium } \\
\text { bigibbum) on tissue culture material. This research was conducted on July 2019. This } \\
\text { RdanD used the ADDIE model without implementation phase. The data collection } \\
\text { instruments used were validation sheets and student questionnaire responses. The } \\
\text { data obtained were analyzed using percentage. The evaluation results of the } \\
\text { audiovisual learning media based on video documentary tissue culture showed that it } \\
\text { was considered as very feasible to be used with an average percentage score of } \\
87.50 \% \text { by tissue culture expert, } 91.87 \% \text { by learning media expert, } 91.66 \% \text { by the } \\
\text { teachers, and } 94.37 \% \text { by the students. The effectiveness of the learning media } \\
\text { developed need to be ensured by conducting the implementation phase. } \\
\text { This is an open access article under the CC-BY-SA license } \\
\text { C. }\end{array}$ \\
\hline $\begin{aligned} \text { How to cite: } & \text { Mellisa, M. \& } \\
& \text { culture explan } \\
& \text { org } / 10.22219 /\end{aligned}$ & $\begin{array}{l}\text { D. (2019). Developing audio-visual learning media based on video documentary on tissue } \\
\text { robium bigibbum. JPBI (Jurnal Pendidikan Biologi Indonesia), 5(3), 379-386 doi: https://doi. } \\
993\end{array}$ \\
\hline
\end{tabular}

\section{INTRODUCTION}

Teaching and learning process is information delivery from facilitator to the acceptor/students (Ghavifekr \& Rosdy, 2015; Gleason et al., 2011). Aside from being knowledge conveyor for students, a learning facilitator is also regulator of learning process and his/her classroom environment (Rodman, 2010). Learning process is influenced by internal factors such as attitudes, view of life, pleasure and displeasure feelings, habits and student experiences (Tyng, Amin, Saad, \& Malik, 2017; Visser, Korthagen, \& Schoonenboom, 2018). Moreover, various external factors also stimulate students in terms of their senses, particularly their hearing and vision (Asmara, 2015). In accordance with the external factors, learning media play a crucial role in influencing instructional processes such as capturing certain object or event; manipulating certain circumstances, events or objects; giving equitable learning opportunities; ensuring teaching process in more knowledge-based condition; displaying a too-large objects to carry to a classroom; magnifying and clarifying 
too-small objects which are too difficult to see with naked eyes (Restiyani, 2014). Along with the advancement of information technology, media has become an interesting study in many disciplines, although with a slightly different naming (Mahnun, 2012).

In nowadays modern learning system, not only do students act as recipients of messages, but they also act as communicators or messengers. Thus, it is called two-way communication and multi-directional communication in which media is strongly needed to improve the effectiveness of learning objectives. In other words, learning process will occur if there is good communication between message contributor and receiver through the media (Kurniawan, 2013).

However, some previous studies reported that there are several factors contributed in the ineffectiveness of media learning (Clark, Yates, Early, \& Moulton, 2013) which means that the improvement of learning media need to be done. One of the learning media is audio-visual media which is believed to be able to increase the students' interest on their lectures. It is also an alternative means of conducting technology-based learning processes as its role in optimizing learning process. By employing the media, several benefits can gained by users i.e. a) easily packaged in learning process, b) more interesting for learners, and c) can be edited/corrected anytime. To be more detail, audio-visual learning media is useful to convey more interesting subject matter, including visualization of teaching material, as well as to create more interactive circumstance as a two-way traffic communication in learning process is more likely to occur (Haryoko, 2012).

Documentary audio-visual media is anything that allows radio signal to be combined with sequence moving images. The advantage, in term of visualizing material, possessed by video is potentially effective in delivering dynamic concepts such as motor movement, facial expressions, or certain environmental situations in attractive way (Batubara, 2017). Moreover, by utilizing video, many concepts and descriptions can be learnt clearly and interestingly; in addition, it helps students to achieve cognitive, psychomotor, and affective goals in the learning process (Putri, Titin, \& Santoso, 2019). Therefore, students will be encouraged to optimize their senses as the media served them the combination of sound and images. Thus, profound understanding will be enacted by students through engaging their senses (at least listening and watching) in comprehending the phenomenon occurs. As it is comprised of documentations of facts in life (Tejawati et al., 2019), a documentary video about tissue culture practical works is expected to give the similar effect to students who are taught using this media for tissue culture concept in school.

Tissue culture is technique of plant propagation by multiplying micro tissues plant that are cultured in vitro to grow as a complete plants, in term of possessing shoots, leaves, and roots (Rahmah, Rahayu, \& Hayati, 2018), as they are placed in an appropriate environment (Kartiman, Sukma, Aisyah, \& Purwito, 2018). It produces superior uniform plants in large quantities (Lestari, 2011). Ideally, tissue culture materials are delivered for a semester due to the complexity and great amount of the concepts which must be mastered by students to get a complete description about it. Nevertheless, it becomes a hindrance to give tissue culture material in senior high school as the limited time given which only in one meeting. In addition, to date, teachers have been only rely on power points, worksheets, and books to support their teaching-learning activities. As the consequences, it is difficult for students to understand the materials as they are not interested in these learning media. Therefore, it is important to develop a proper learning media to achieve the expected learning outcome determined in term of the better students' understanding about tissue culture material. To improve the quality of meaningful learning process which improves the quality of learning outcomes, educators are required to always think and try to develop their learning activities (Prasetyo, 2014). This study aimed at producing an audio-visual learning media based on tissue culture documentary video of Larat orchid plants (Dendrobium bigibbum).

\section{METHOD}

This Research and Development (R \& D) was conducted on July 2019 in SMA Negeri 9 Pekanbaru, MAN 2 Model Pekanbaru, and As-Shofa Islamic High School Pekanbaru, Riau Province-Indonesia. The audio-visual learning media of tissue culture was developed according to the ADDIE model (Branch, 2009) without implementation stage. The ADDIE model covered Analysis, Design, Development, Implementation and Evaluation (Purbasari, Kahfi, \& Yunus, 2013). The reduction of the ADDIE steps was based on Mahnun (2012). The documentary video contained of tissue culture preparation of Larat orchid, tissue culture step, and maintaining the culture until planlet. 


\section{ADDIE step for making learning media of tissue culture}

The analysis stage was done by conducting curriculum, needs, and student analysis. Meanwhile, in the Design stage, the design of learning media content was done. The learning media was composed based on the core of competencies and basic competencies stated in the Curriculum 2013. To be more specific, the media comprised of learning objective, main materials, and conclusions (Tegeh \& Kirna, 2013).

Furthermore, the Development stage was conducted in three steps i.e. documenting tissue culture laboratory work, combining video documentations, as well as providing additional filters and sound into the learning media. Moreover, the documentary video was created using the Wonder share Filmora9 application. As the final stage in this research, the Evaluation stage was done by conducting learning media validation which was aided by validator who was asked to fulfill a questionnaire. The ADDIE stages used in this research can be seen in Figure 1.

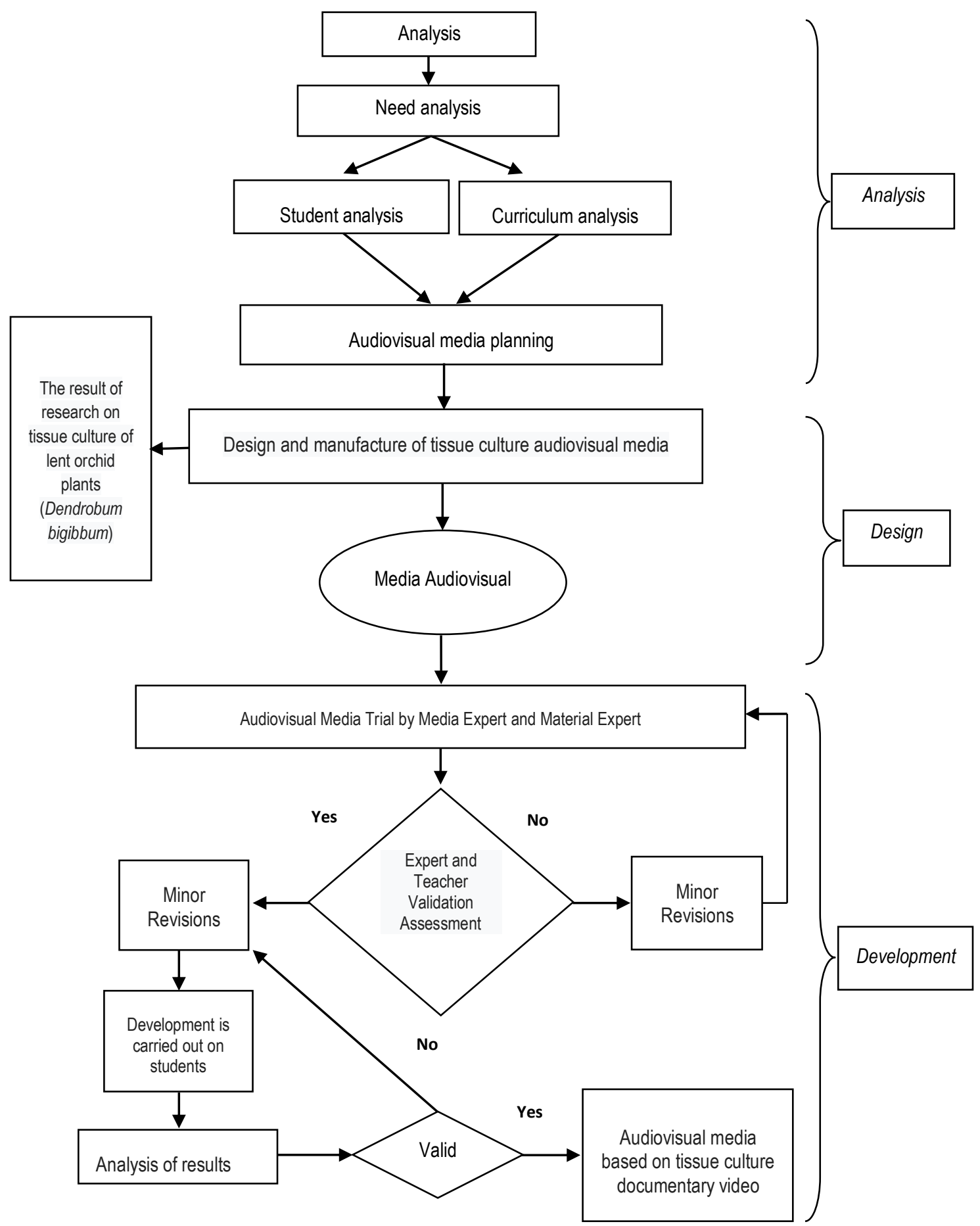

Figure 1. Procedures of ADDIE (Analysis to the stage of Development) (Hayati et al., 2015) 


\section{Step for making the video documentary of tissue culture}

The documentary video was made in three steps: pre-production, video production, and post-production (Dharmawan \& Wahyuni, 2017). First, pre-production comprised of planning and preparation which included several activities such as identifying and determining media programs, preparing media content outline (or Garis-Garis Besar Isi Media/GBIM), preparing of material media description (or Jabaran Media Material/JMM), compiling manuscripts of tissue culture learning media.

Second, the video production covered several activities i.e. script discussion, hunting, canting, budgeting, research and preparation of the tissue culture work stages in laboratory, shooting and video recording. Third, the post-production included editing, expert validation, trial, revision, and publishing. The documentary video of tissue culture was validated by learning media expert, learning material experts and students. The documentary video learning media was reproduced by transferring video files using flash disc, thus, the video is easily used (Tejawati et al., 2019).

The data was collected by using questionnaire and validation sheet to develop the documentary audiovisual media of tissue culture. The validation sheets was given to the validators to assess the audio-visual learning media. Moreover, the questionnaire was also given to teacher and students for evaluation process the tissue culture audiovisual media. Questionnaire responses of students are used to determine students' responses to audio-visual learning media. The student questionnaire responses were filled in by 15 students who had studied tissue culture material from each school.

The instrument used for data collection was questionnaire with Likert scale. It was used to measure individual response toward the media by choosing the points served on each question: strongly agree, agree, disagree, disagree, and strongly disagree (Budiaji, 2013). The eligibility criteria according to validator assessment can be seen in the Table 1.

Table 1. Eligibility criteria according to validator assessment

\begin{tabular}{ccr}
\hline No. & Eligibility criteria (\%) & Level of eligibility \\
\hline 1 & $85.01-100$ & Very valid, or very effective (very complete), can be used without revision \\
2 & $70.01-85$ & Fair, effective enough (quite complete), can be used but needs minor improvements. \\
3 & $50.01-70$ & Invalid, or less effective (incomplete), needs major improvement \\
4 & $1.00-50$ & Invalid, or ineffective (incomplete), cannot be used. \\
\hline (Source: Wahyuni \& Mustadi, 2016) &
\end{tabular}

The data obtained from questionnaire was analyzed using eligibility criteria made by Wahyuni and Mustadi (2016) as served in Table 2.

Table 2. The eligibility criteria percentage of student response questionnaire

\begin{tabular}{ccc}
\hline No. & Eligibility criteria (\%) & Level of eligibility \\
\hline 1 & $85.01-100$ & Very feasible, or very effective (very complete), can be used without revision \\
2 & $70.01-85$ & Quite feasible, quite effective (quite thorough), can be used but needs minor revision \\
3 & $50.01-70$ & Poor, or ineffective (incomplete), needs major revision \\
4 & $1.00-50$ & Inappropriate, or ineffective (incomplete), cannot be used \\
\hline (Source: Wahyuni \& Mustadi, 2016) &
\end{tabular}

\section{RESULTS AND DISCUSSION}

This study was conducted to find out whether the media made is feasible as an interactive learning media or not. As the media has been validated and fulfilled all criteria as well as does not need a revision, means that the learning media is ready to be implemented (Azhar, 2008). To reach the criteria, experts' opinion is important as considerable suggestions to revise a developed media so that its completeness and design suitability to the interested materials are met (Dewi, 2012; Aditya, 2018). Therefore, the documentary audio-visual learning media developed in this study was also assessed by experts to ensure that the media is feasible to use.

The validation results of documentary audio-visual learning media are served in Table 3 . It can be seen that based on the content expert assessment, the learning media developed was highly valid as the percentage score gained as high as $87.5 \%$. This also means that the learning media did not need to be revised to be implemented. For further elaboration, the results also imply that the audiovisual media learning about the orchid tissue culture have fulfilled the standard of the learning media in term of the material suitability to learning objectives, the depth of material, easy understood, the clarity of description and discussion, and the language simplicity for high school students. It means that the material has met the technical considerations in subject 
matter. The results are in line with the finding of Arsanti (2018) that the substance of the material is accumulated from competency standards which is set out in the curriculum, easy to understand and attractive.

Table 3. Validation results of audio-visual learning media by material experts

\begin{tabular}{ccccc}
\hline No & Validator name & Rated aspect & Percentage of eligibility (\%) & Eligibility level \\
\hline 1. & SA & Content eligibility & 87.50 & Very valid \\
\hline \multicolumn{2}{l}{ Average material expert's rating of content eligibility } & 87.50 & very valid \\
\hline
\end{tabular}

The media experts focused their assessment on software engineering and audio visual communication aspects of the media developed. The validation results of media expert are served in Table 4. Based on the results, it can be concluded that the software engineering and visual communication aspects were very valid as the percentage achieved was $91.87 \%$. Thus, the media has met the demands of the 21 st-century learning media criteria which expected that the digital media should be used by students to communicate, interact, collaborate and share information together using various digital media (Sidek \& Hashim, 2016).

Table 4. Validation results of audio visual learning media by media experts

\begin{tabular}{ccccc}
\hline No & Validator name & Rated aspect & Percentage of eligibility (\%) & Eligibility level \\
\hline 1. & SR & Software engineering & 93.75 & Very valid \\
2. & RV & Audio visual communication & 90.00 & Very valid \\
& Software engineering & 93.75 & very valid \\
& & Audio visual communication & 90.00 & Very valid \\
\hline
\end{tabular}

Table 5 shows the results of teacher responses about the documentary audio-visual media developed. It can be seen that the positive responses were paid by the teachers. They considered that the media has reached $91.66 \%$ of $100 \%$ need to achieve, which means that it was categorized as very valid. It also implies that the documentary audio-visual learning media developed was feasible, from teachers' perspective. Moreover, the learning media was in line with the learning objectives, the material descriptions have met students' competencies, continuous, and easy understood.

Table 5. The results of audio visual learning media validation by teachers

\begin{tabular}{|c|c|c|c|c|c|c|}
\hline \multirow{2}{*}{ No } & \multirow{2}{*}{ Rated aspect } & \multicolumn{3}{|c|}{ Percentage of eligibility (\%) } & \multirow{2}{*}{ Average (\%) } & \multirow[b]{2}{*}{ Eligibility level } \\
\hline & & JE & $E$ & A & & \\
\hline 1 & Content Eligibility & 87.50 & 95.83 & 91.66 & 91.66 & Very valid \\
\hline \multicolumn{5}{|c|}{ Average on all aspects } & 91.66 & Very valid \\
\hline
\end{tabular}

In accordance with learning activities, teachers' opinion is crucial to assess the learning media. As teachers' competencies in determining instructional media should cover the ability in recognizing the most effective media to deliver the materials, the media function to enact the education goals, the values and benefits of learning media as well as the use of learning media (Prastya, 2016), their view is needed to give the researchers evaluation and consideration to make the product developed is better and better.

Besides teachers' evaluations, students' rate is also needed to give an evaluation for the learning media, because they are the participant who will receive as well as user of the media. In this research, students' questionnaire was included three assessment aspects, which were modified from Rizqa Safitri, Budiharti, \& Yusliana Ekawati, (2014) i.e. 1) media aspect with the indicators: video operation, display, back sound, and suitability to clarify content; 2) material aspect with the indicators: learning objectives, video conformity to clarify material, comprehensiveness, language, presentation, relevance, and narration clarity; 3) benefit aspect with the indicators: learning facilities, material attractiveness, the ability in fostering curiosity (see Table 5). The results of students' responses to the documentary audio-visual learning media are served in Table 6.

It is obvious served in Table 6 that the all aspects assessed were positively responded by student as very good media (94.37\%). This means that the developed media has good attractiveness, good message delivery, as well as user friendly. To go more detail, based on these findings, the developed media is feasible in terms of easy to be operated by students, the display is interesting, and the back sound is supporting the learning activity during utilizing the media; moreover, the all components in the media are suitable to create a good understanding for students in term of enunciating tissue culture concept. Thus, the students rated the media aspect as high as $94.59 \%$. 
Table 6. Students' responses about the eligibility of documentary audio-visual learning media

\begin{tabular}{ccccccc}
\hline \multirow{2}{*}{ No } & \multirow{2}{*}{ Rated aspect } & \multicolumn{2}{c}{ Percentage of eligibility (\%) } & \multirow{2}{*}{ Average (\%) } & \multirow{2}{*}{ Eligibility level } \\
\cline { 3 - 4 } & Aspects of media & 94.75 & 94.51 & 94.52 & 94.59 & Very good \\
2 & Material aspects & 91.66 & 96.66 & 94.71 & 94.34 & Very good \\
3 & Benefits aspect & 91.66 & 96.42 & 94.52 & 94.20 & Very good \\
\hline \multicolumn{2}{r}{ Average on all aspects (\%) } & 92.69 & 95.86 & 94.58 & 94.37 & Very good \\
\hline
\end{tabular}

In addition, students considered that the materials covered in the media were in line with learning objectives, the content conformity has clarified the comprehensive material, as well as the language used, presentation, and narration were clear. In other words, the developed media can be accepted and easily used by students. Furthermore, by using the media, they will benefit various learning facilities, and more attractive materials which fostered their curiosity. These findings were supported by Dharmawan and Wahyuni (2017) who stated that a learning media is valid if the all aspects were assessed in similar values by students/user.

\section{CONCLUSION}

Based on the results of the study, it can be concluded that the documentary audio-visual learning media of tissue culture was categorized as very valid criteria. The percentage of validation results of material and media experts as well as teachers were $87.50 \%, 91.87 \%$, and $91.66 \%$ respectively. This was supported by the positive response by students so that the media was categorized as very good (94.37\%).

\section{REFERENCES}

Aditya, P. T. (2018). Pengembangan media pembelajaran matematika berbasis web pada materi lingkaran bagi siswa kelas VIII. Jurnal Matematika Statistika Dan Komputasi, 15(1), 64-74. doi: https://doi.org/10.20956/jmsk.v15i1.4425

Arsanti, M. (2018). Pengembangan bahan ajar mata kuliah penulisan kreatif bermuatan nilai-nilai pendidikan karakter religius bagi mahasiswa prodi pbsi, fkip, unissul. KREDO : Jurnal IImiah Bahasa Dan Sastra, 1(2), 72-90. doi: https://doi.org/10.24176/kredo.v1i2.2107

Asmara, A. P. (2015). Pengembangan media pembelajaran berbasis audio visual tentang pembuatan koloid. Jurnal IImiah Didaktika, 15(2), 156. doi: https://doi.org/10.22373/jid.v15i2.578

Azhar, A. (2008). Media pembelajaran; Edisi revisi. Repositori Riset Kesehatan Nasional. Jakarta. http:/l perpustakaan.bppsdmk.kemkes.go.id//index.php?p=show_detaildanid=4667

Batubara, M. S. (2017). Hasil uji coba video pembelajaran mata kuliah kultur jaringan berbasis masalah pada dosen dan mahasiswa program studi pendidikan biologi UMTS. Jurnal Pendidikan Biologi, 6(2), 267273. doi: https://doi.org/10.24114/jpb.v6i2.6544

Branch, R. M. (2009). Instructional design: The ADDIE approach (Vol. 722). Boston, MA: Springer US. https:// doi.org/10.1007/978-0-387-09506-6

Budiaji, W. (2013). Skala pengukuran dan jumlah respon skala likert. Jurnal IImu Pertanian Dan Perikanan, 2(2), 127-133. Retrieved from http://umbidharma.org/jipp

Clark, R. E., Yates, K., Early, S., \& Moulton, K. (2013). An analysis of the failure of electronic media and discovery-based learning: Evidence for the performance benefits of guided training methods. Retrieved from http://citeseerx.ist.psu.edu/viewdoc/download?doi=10.1.1.458.2396danrep=rep1dantype=pdf

Dewi, G. P. F. (2012). Pengembangan game edukasi pengenalan nama hewan dalam bahasa inggris sebagai media pembelajaran siswa sd berbasis macromedia flash. Universitas Negeri Yogyakarta. Retrieved from https://core.ac.uk/download/pdf/11066087.pdf

Dharmawan, A., \& Wahyuni, A. (2017). Model pembelajaran membaca berbasis audio-video untuk siswa tunagrahita. Jurnal Kependidikan: Penelitian Inovasi Pembelajaran, 1(2), 174-186. Retrieved from https://media.neliti.com/media/publications/197330-ID-audio-video-based-reading-learning-model.pdf

Ghavifekr, S., \& Rosdy, W. A. W. (2015). Teaching and learning with technology: Effectiveness of ICT integration in schools. International Journal of Research in Education and Science, 1(2), 175-191. doi: https://doi.org/10.21890/ijres.23596

Gleason, B. L., Peeters, M. J., Resman-Targoff, B. H., Karr, S., McBane, S., Kelley, K., ... Denetclaw, T. H. (2011). An active-learning strategies primer for achieving ability-based educational outcomes. American 
Journal of Pharmaceutical Education, 75(9), 186 (1-12). doi: https://doi.org/10.5688/ajpe759186

Haryoko, S. (2012). Efektivitas pemanfaatan media audio-visual sebagai alternatif optimalisasi model pembelajaran. Jurnal Edukasi Elektro, 5(1), 1-10. Retrieved from https://s3.amazonaws.com/academia. edu.documents/40894083/jurnal_efektivitas.pdf?response-content-disposition=inline\%3B filename\%3D Jurnal_efektivitas.pdfdanX-Amz-Algorithm=AWS4-HMAC-SHA256danX-Amz-Credential=AKIAIWOWY YGZ2Y53UL3A\%2F20191229\%2Fus-east-1\%2Fs3\%2Fa

Hayati, S., Budi, A. S., \& Handoko, E. (2015). Pengembangan media pembelajaran flipbook fisika untuk meningkatkan hasil belajar peserta didik. In Prosiding Seminar Nasional Fisika (e-jurnal) SNF2015 (Vol. 4, pp. 49-61). Retrieved from http://journal.unj.ac.id/unj/index.php/prosidingsnf/article/view/4810/3587

Kartiman, R., Sukma, D., Aisyah, S. I., \& Purwito, A. (2018). Multiplikasi in vitro anggrek hitam (Coelogyne pandurata Lindl.) pada perlakuan kombinasi naa dan bap. Jurnal Bioteknologi dan Biosains Indonesia (JBBI), 5(1), 75. doi: https://doi.org/10.29122/jbbi.v5i1.2908

Kurniawan, A. D. (2013). Metode inkuiri terbimbing dalam pembuatan media pembelajaran Biologi untuk meningkatkan pemahaman konsep dan kreativitas siswa SMP. Jurnal Pendidikan IPA Indonesia, 2(1), 1-10. doi: https://doi.org/https://doi.org/10.15294/jpii.v2i1.2503

Lestari, E. G. (2011). Peranan zat pengatur tumbuh dalam perbanyakan tanaman melalui kultur jaringan. Jurnal AgroBiogen, 7(1), 63-68. doi: https://doi.org/10.21082/jbio.v7n1.2011.p63-68

Mahnun, N. (2012). Media pembelajaran (Kajian terhadap langkah-langkah pemilihan media dan implementasinya dalam pembelajaran). An-Nida', 37(1), 27-34. Retrieved from http://ejournal.uinsuska.ac.id/index.php/Anida/article/view/310

Prasetyo, I. (2014). Teknik analisis data dalam research and development. Yogyakarta: Universitas Negeri Yogyakarta. Retrieved from http://staffnew.uny.ac.id/upload/132310875/pengabdian/teknik-analisis-data -dalam-research-and-development.pdf

Prastya, A. (2016). Strategi pemilihan media pembelajaran bagi seorang guru. In Temu Ilmiah Nasional Guru (Ting) Viii (pp. 294-302). Jakarta: UT. Retrieved from http://repository.ut.ac.id/6518/

Purbasari, R. Julia, Kahfi, M. S., \& Yunus, M. (2013). Pengembangan aplikasi android sebagai media pembelajaran matematika pada materi dimensi tiga untuk siswa SMA kelas X. In Jurnal Online Universitas Negeri Malang (pp. 1-11). Retrieved from http://jurnal-online.um.ac.id/data/artikel/artikel2C 484B69ABB15E4060342947D84D09F8.pdf

Putri, R. G., Titin, T., \& Santoso, R. (2019). Film dokumenter pemanfaatan tumbuhan berkhasiat obat sebagai media pembelajaran materi sistem pencernaan. Jurnal Pendidikan Sains Indonesia (Indonesian Journal of Science Education), 7(2), 121-131. doi:https://doi.org/10.24815/jpsi.v7i2.14808

Rahmah, S., Rahayu, T., \& Hayati, A. (2018). Kajian penambahan bahan organik pada media tanam VW pada organogenesis anggrek Dendrobium secara in vitro. Jurnal Sains Alami, 1(1), 93-103. doi: https:// doi.org/10.33474/j.sa.v1i1.1392

Restiyani, R. (2014). Profil pemanfaatan teknologi informasi dan komunikasi (tik) sebagai media dan sumber pembelajaran oleh guru biologi. EDUSAINS, 6(1), 49-66. doi: https://doi.org/https://doi.org/10.15408/es. v6i1.1100

Rizqa Safitri, M., Budiharti, R., \& Yusliana Ekawati, E. (2014). Pengembangan media pembelajaran IPA terpadu interaktif dalam bentuk MOODLE untuk siswa SMP pada tema hujan asam. Jurnal Pendidikan Fisika Universitas Sebelas Maret, 15(1), 1-14. doi: https://doi.org/10.20956/jmsk.v15i1.4425

Rodman, G. J. (2010). Facilitating the teaching-learning process through the reflective engagement of preservice teachers. Australian Journal of Teacher Education, 35(2), 20-34. Retrieved from https://search. informit.com.au/documentSummary; $d n=850772650818358$; res=IELAPA

Sidek, S., \& Hashim, M. (2016). Pengajaran berasaskan video dalam pembelajaran berpusatkan pelajar: analisis dan kajian kritikal. Journal of ICT in Education (JICTIE), 3(1), 24-33. Retrieved from http://ir. upsi.edu. my/id/eprint/316

Tegeh, I. M., dan Kirna, I. M. (2013). Pengembangan bahan ajar metode penelitian pendidikan dengan addie model. Jurnal Ika, 11(1), 12-20. doi: https://doi.org/http://dx.doi.org/10.23887/ika.v11i1.1145

Tejawati, A., Pradana, E. K., Firdaus, M. B., Suandi, F., Lathifah, L., \& Anam, M. K. (2019). Pengembangan video dokumenter "wanita dan informatika" di lingkungan FKTI Universitas Mulawarman. Jurnal Informatika Dan Rekayasa Elektronik, 2(2), 72. doi: https://doi.org/10.36595/jire.v2i2.121

Tyng, C. M., Amin, H. U., Saad, M. N. M., \& Malik, A. S. (2017). The influences of emotion on learning and memory. Frontiers in Psychology, 8(AUG). doi: https://doi.org/10.3389/fpsyg.2017.01454 
Visser, L., Korthagen, F. A. J., \& Schoonenboom, J. (2018). Differences in learning characteristics between students with high, average, and low levels of academic procrastination: Students' views on factors influencing their learning. Frontiers in Psychology, 9(MAY), 1-15. doi: https://doi.org/10.3389/fpsyg.20 18.00808

Wahyuni, M., \& Mustadi, A. (2016). Pengembangan perangkat pembelajaran collaborative learning berbasis kearifan lokal untuk meningkatkan karakter kreatif dan bersahabat. Jurnal Pendidikan Karakter, 6(2), 1 13. Retrieved from https://journal.uny.ac.id/index.php/jpka/article/view/12056 